Gut, 1977, 18, 749-753

\title{
Humoral immune system in inflammatory bowel disease: I. Complement levels
}

\author{
H. J. F. HODGSON, B. J. POTTER, AND D. P. JEWELL \\ From the Academic Department of Medicine, Royal Free Hospital, London
}

SUMmaRY Serum levels of complement components Clq, C4, C3, and Properdin factor B, from the classical and alternative pathways of complement activation, have been estimated in patients with ulcerative colitis and Crohn's disease. C3, factor B, and to some extent C4 concentrations all increased when the disease was active. In remission the levels of these components did not differ from hospital control patients. There was no evidence for the preferential consumption of the proteins of either pathway of activation, even in those patients with evidence of circulating immune complexes.

The complement system in man is a major mechanism by which immune processes lead to inflammation and tissue damage. When activated, proteins are produced which increase vascular permeability, release vasoactive amines from mast cells and platelets, and mediate cell lysis. Activation of complement may be initiated by a number of factors, which include antigen-antibody complexes, bacterial endotoxin, and various proteolytic enzymes.

In ulcerative colitis and Crohn's disease, immune complexes have been found in the circulation (Doe et al., 1973; Jewell and MacLennan, 1973); endotoxin has also been reported in the serum of these patients (Bowen and Kirsner, 1965). It therefore seems probable that complement activation occurs in these diseases.

The present study investigated the levels of complement components, from both the classical (C1q, C4, C3) and alternative pathways (factor B, C3) of activation, in the sera of patients with ulcerative colitis and Crohn's disease, correlating these with the clinical features. Data on the presence of immune complexes in the same sera were obtained (Hodgson et al., 1977).

\section{Methods}

\section{PATIENTS}

Blood was obtained from 93 patients with ulcerative colitis, 66 patients with Crohn's disease, 20 healthy controls, and 31 hospital control patients, with diseases thought not to affect their immune Received for publication 16 February 1977 system. This latter group included patients with angina, peptic ulcer, hereditary hyperbilirubinaemia, and lumbar disc lesions. Ulcerative colitis and Crohn's disease were diagnosed on conventional clinical, radiological, and histological criteria, and their disease activity was graded according to the criteria of Truelove and Witts (1955) for ulcerative colitis, and de Dombal et al. (1974) for Crohn's disease. Patients with significant liver disease associated with inflammatory bowel disease had all undergone liver biopsy.

ESTIMATION OF COMPLEMENT COMPONENTS

Sera were separated within four hours of collection, and stored in aliquots at $-70^{\circ} \mathrm{C}$ until use. They were then thawed at room temperature, and serum levels of $\mathrm{C} 1 \mathrm{q}, \mathrm{C} 4, \mathrm{C} 3$, and factor $\mathrm{B}$ (C3 proactivator, $\mathrm{GBG}$ ) were estimated by single radial immunodiffusion. C1q was estimated in $1 \%$ agarose plates made in phosphate-buffered saline (PBS) $\mathrm{pH} 7 \cdot 2$, containing antihuman $\mathrm{C} 1 \mathrm{q}$ serum (Behringwerke) at a concentration of $0.015 \mathrm{ml} / \mathrm{ml}$ of agarose solution. Sera were diluted 1 in 2 in PBS. A standard curve was constructed on each occasion, using serial dilutions of a pool of sera from 18 hospital control patients. This pool was stored in aliquots at $-70^{\circ} \mathrm{C}$ and a separate sample thawed on each occasion. Plates were read after 18 hours. C4 was estimated in $1 \%$ agarose plates in PBS containing Hyland antihuman C4 serum, at a concentration of $0.22 \mathrm{ml} / \mathrm{ml}$ of agarose solution. Behringwerke protein standard plasma was used to construct a standard curve on each occasion. Sera were diluted 1 in 4 before testing. The plates 
Table Serum complement components in patients with inflammatory bowel disease and control subjects (mean values $\pm S E$ )

\begin{tabular}{|c|c|c|c|c|c|}
\hline & No. & $\begin{array}{l}\text { Clq } \\
(\% \text { control pool })\end{array}$ & $\begin{array}{l}C 4 \\
(m g / D)\end{array}$ & $\begin{array}{l}C 3 \\
(m g / l)\end{array}$ & $\begin{array}{l}\text { Factor B } \\
(m g / l)\end{array}$ \\
\hline Ulcerative colitis & 93 & $1040 \pm \frac{17}{\text { (NS) }}$ & $522 \pm \underset{(N S)}{21}$ & $\begin{aligned} 1320 & \pm 31 \\
(\mathrm{P} & <0.01)\end{aligned}$ & $\begin{array}{l}201 \pm 7 \\
(P<0.05)\end{array}$ \\
\hline Crohn's disease & 66 & $977 \pm 21$ & $570 \pm 26$ & $\begin{aligned} 1460 & \pm 43 \\
(P & <0.01)\end{aligned}$ & $\begin{aligned} 232 & \pm 9 \\
(P & <0.05)\end{aligned}$ \\
\hline Hospital controls & 31 & $975 \pm 27$ & $\begin{array}{l}580 \pm 27 \\
\quad(P<0.05)\end{array}$ & $\begin{aligned} 1270 & \pm 47 \\
(P & <0.05)\end{aligned}$ & $\begin{aligned} & 175 \pm 8 \cdot 5 \\
&(\mathrm{NS})\end{aligned}$ \\
\hline Healthy controls & 20 & $1023 \pm 33$ & $465 \pm 27$ & $1040 \pm 50$ & $166 \pm 10$ \\
\hline
\end{tabular}

P values refer to the comparison with the healthy control group.

were read after 18 hours. C3 was estimated using Hyland immunoplates and Hyland standards. Sera were tested undiluted, and the plates were read after 18 hours.

Properdin factor $B$ This was estimated using Behringwerke C3 activator plates. Behringwerke plasma protein standards were used. Sera were diluted 1 in 2 before testing. Plates were read after 48 hours.

C3 activation Those sera containing more than $2 \mathrm{~g} / \mathrm{l}$ of $\mathrm{C} 3$ were tested for evidence of $\mathrm{C} 3$ activation by two-dimensional immunoelectrophoresis against antihuman C3 (Hyland).

STATISTICAL METHODS

Comparisons between groups were made using Student's $t$ test.

\section{Results}

The mean serum levels of $\mathrm{C} 1 \mathrm{q}, \mathrm{C} 4, \mathrm{C} 3$, and factor $\mathrm{B}$ obtained in the four groups of patients studies are shown in the Table.

C1q

The mean level for patients with ulcerative colitis was significantly higher than the mean level for patients with Crohn's disease $(P<0.025)$. There were no other significant differences between groups.

\section{C4}

There was no significant difference between the hospital patients and the patients with ulcerative colitis or Crohn's disease. The mean level for the healthy control subjects was significantly lower for the hospital control patients $(P<0.05)$.

\section{C3}

Patients with Crohn's disease had a higher mean C3 level than patients with ulcerative colitis or either of the control groups $(\mathrm{P}<0.01)$. The mean for the patients with ulcerative colitis did not differ significantly from the hospital control patients. The mean level for healthy controls was significantly lower than for hospital control patients $(P<0.05)$.

\section{FACTOR B}

Both patients with ulcerative colitis and with Crohn's disease had significantly higher mean factor B levels than either control group $(P<0.05)$. The mean for Crohn's disease was higher than that for ulcerative colitis $(P<0.025)$. The two control groups did not differ significantly.

\section{SITE AND EXTENT OF DISEASE}

Levels of C3 were significantly higher in patients with ulcerative colitis when the area of colon involved was substantial rather than distal (mean C3 = $1380 \pm 40 \mathrm{mg} / \mathrm{l}$ and $1260 \pm 40 \mathrm{mg} / \mathrm{l}$ respectively, $P<0.05)$. The mean factor $B$ levels were also higher in patients with substantial colitis compared with those with distal colitis $(220 \pm 9.5 \mathrm{mg} / \mathrm{l}$ and $174 \pm$ $8 \mathrm{mg} / \mathrm{l}$ respectively, $\mathrm{P}<0.005$ ). There was no difference between the mean levels of $\mathrm{Clq}$ and $\mathrm{C} 4$ between these groups.

For patients with Crohn's disease, no correlation was found between the site of disease and the mean levels of any of the complement components measured.

\section{ACTIVITY OF DISEASE}

For both ulcerative colitis and Crohn's disease, there was a tendency for the levels of C3 and factor B to rise with increasing activity of disease. For $\mathrm{C} 4$, a similar correlation was seen only in ulcerative colitis. No correlation with disease activity was found for $\mathrm{Clq}$ in either group.

Eighteen patients (11 with ulcerative colitis, seven with Crohn's disease) were studied as they passed from relapse to remission. The levels of $\mathrm{C} 3$ and factor B fell significantly (Fig. 1) but there were no consistent alterations in the levels of $\mathrm{C} 1 \mathrm{q}$ and $\mathrm{C} 4$ (Fig. 2). 

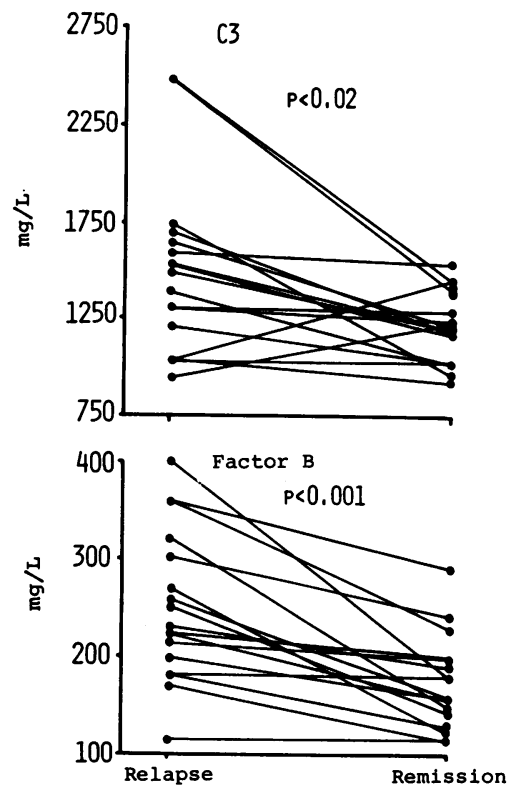

Fig. 1 Serum C3 and factor B concentrations in 18 patients followed up from relapse to remission.
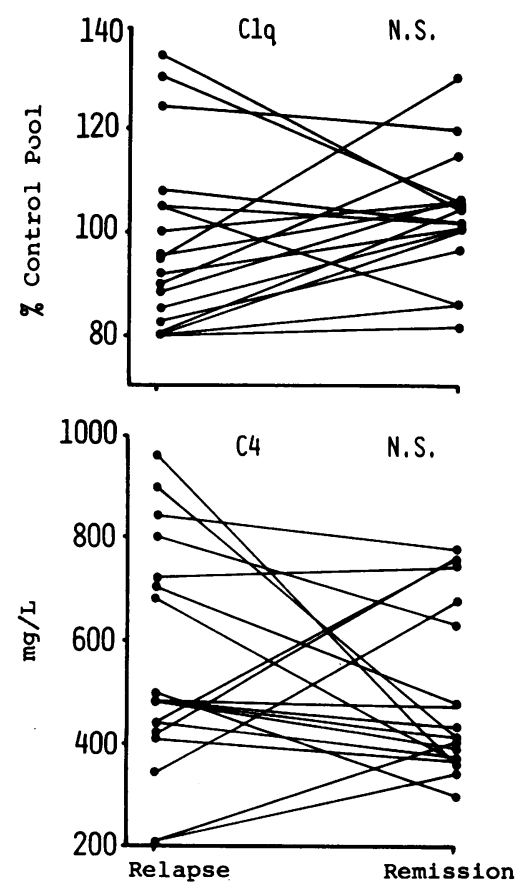

Fig. 2 Serum Clq and C4 concentrations in 18 patients followed up from relapse to remission.
EFFECTS OF THERAPY

There were no differences in the mean levels of any of these complement components for patients on or off systemic corticosteroid therapy. This was so for the whole group of patients with each disease, and also when groups of patients with the same degree of disease activity were compared.

\section{EXTRAINTESTINAL MANIFESTATIONS}

In those patients with arthritis or eye or skin complications, there was no tendency for the levels of complement components to fall, and the mean levels did not differ from the mean levels of the disease groups as a whole. Among 17 patients with liver disease (one with inactive cirrhosis, seven with chronic active hepatitis and cirrhosis, six with sclerosing cholangitis, and four with pericholangitis) mean $\mathrm{C} 4$ levels were significantly lower $(408 \pm 34$ $\mathrm{mg} / \mathrm{l})$ than for patients without liver disease (558 \pm $26 \mathrm{mg} / \mathrm{l}, \mathrm{P}<0.05)$.

\section{IMMUNE COMPLEXES}

In patients in whom the presence of immune complexes had been indicated by excessive anticomplementary activity, in the sera (Hodgson et al., 1977), mean factor B levels were significantly raised $(252 \pm$ $12 \mathrm{mg} / \mathrm{l}$ with excess anticomplementary activity, 199 $\pm 5.5 \mathrm{mg} / \mathrm{l}$ without; $\mathrm{P}<0.001$ ). There was no significant difference for $\mathrm{Clq}$ or $\mathrm{C} 4 ; \mathrm{C} 3$ tended to be higher in patients with excess anticomplementary activity $(1440 \pm 50 \mathrm{mg} / \mathrm{l}$ with, $1350 \pm 29 \mathrm{mg} / \mathrm{l}$ without), but the difference is not significant $(\mathrm{P}=$ $\mathbf{0} \cdot \mathbf{1}$ ).

\section{CORRELATION BETWEEN INDIVIDUAL COMPONENTS}

The levels of $\mathrm{C} 4, \mathrm{C} 3$, and factor B correlated positively among the patients with inflammatory bowel disease. The correlations were weak with $r$ values from 0.306 to $0.529, \mathrm{P}<0.001$. C1q levels failed to correlate with $\mathrm{C} 3$ or factor $\mathrm{B}$, but showed a weak positive correlation with $\mathrm{C} 4(r=0.192, \mathrm{P}<0.01)$.

c3 activation No evidence of $\mathrm{C} 3$ activation was found in those sera examined.

\section{Discussion}

This study of the serum concentration of four complement proteins in inflammatory bowel diseases confirms the reports of others that the levels tend to be higher when the disease is most active (Ward and Eastwood, 1974; Feinstein et al., 1976). This was particularly marked for C3 and factor B, and occurred in both ulcerative colitis and Crohn's disease. The levels of these two proteins were higher in 
Crohn's disease than ulcerative colitis, but there is little reason to believe that this represents a basic difference between the two conditions, as the difficulties in assessing the extent and activity of Crohn's disease clinically are well known.

It is significant that for two of the proteins, C3 and C4, hospital control patients without immunological disorders had a higher mean serum level than healthy control subjects. This difference suggests that minor rises in the serum level of these proteins are non-specific, and common in ill-health. Rises in the levels of C3 and C4 (Ward and Eastwood, 1974) and factor B (Feinstein et al., 1976) in patients with inflammatory bowel disease in remission have been reported, and this has been considered evidence of continuing immunopathology, even when the disease was inactive; however, these workers used healthy subjects as their control group. In this study, the mean levels of $\mathrm{C} 4, \mathrm{C} 3$, and factor $\mathrm{B}$ in remission did not differ from hospital control patients, suggesting that significant complement abnormalities are found only with active disease.

Among patients with liver disease, C4 levels were depressed, the same pattern as that recognised among patients with chronic liver disease unassociated with inflammatory bowel disease (Potter et al., 1973). The significance of the finding is unknown. In patients with joint, skin, and eye lesions, complement levels were not depressed, although there is evidence that these manifestations may be mediated by immune complexes (Hodgson et al., 1977). The presence of normal serum complement levels with a probable immune complex arthritis is paralleled in rheumatoid arthritis (Höyeraal and Mellbye, 1974). Similarly, levels of C4 and C1q were unaltered in patients with excess anticomplementary activity, measured as an index of the presence of immune complexes. Factor B levels were significantly higher among patients with excess anticomplementary activity, and $\mathrm{C} 3$ showed a similar trend, but this may merely reflect the tendency of these three factors to correlate with disease activity.

The pattern of rise in the level of complement protein during active disease is that of acute phase reactants. $\mathrm{C} 3$ and $\mathrm{C} 4$ have been shown to behave in this way in acute inflammatory conditions such as tonsillitis and viral meningitis (Ganrot, 1974). This pattern is emphasised by the tendency of $\mathrm{C4}, \mathrm{C} 3$, and factor $\mathrm{B}$, proteins from both the classical and alternative pathway of complement, to move in parallel. The typical pattern of depressed levels of classical pathway components seen in systemic lupus erythematosus (Kohler and ten Bensel, 1969) or alternative pathway components seen in membranoproliferative glomerulonephritis (Gewurz et al., 1969) or brought about by endotoxin (Gewurz et al., 1968) has not been found in inflammatory bowel disease.

In the present study, C3 levels were measured in serum obtained within four hours of bleeding the patient. As the clotting process itself is known to activate $\mathrm{C} 3$, it is conceivable that $\mathrm{C} 3$ conversion products which diffuse more rapidly in gel, such as $\mathrm{C} 3 \mathrm{c}$, could have given rise to apparently high levels of $\mathrm{C} 3$ as measured by the Mancini technique. It is also possible that some $\mathrm{C} 3$ conversion occurred during the short period between withdrawing the blood from the patient and the freezing of the serum as a result of ageing. However, studies in our own laboratory have shown that the amount of $\mathrm{C} 3$ activation occurring after four hours in serum incubated at room temperature is minimal (Potter, 1975). Furthermore, no evidence of $\mathrm{C} 3$ activation was found in those sera with abnormally high $\mathrm{C} 3$ levels.

The determination of serum complement levels, therefore, has not provided evidence for the activation of the complement sequence in patients with inflammatory bowel disease. Nevertheless, other lines of evidence suggest complement activation in patients with ulcerative colitis and Crohn's disease. C3 breakdown products have been reported in the sera of patients with these diseases (Teisberg and Gjone, 1975), although they have been less frequently found when plasma has been examined (Pepys et al., 1976). Stronger evidence of C3 activation has come from metabolic studies using purified human C3. These have shown an increase in both the fractional catabolic rate and synthesis rate of $\mathrm{C} 3$, compared with control subjects (Hodgson ct al., 1975). The nature of the factor initiating this activation is uncertain, but antigen-antibody interactions within the diseased mucosa, as well as bacterial endotoxin, seem likely to play a role.

We would like to thank Dr J. Lennard-Jones for allowing us to study patients under his care. H. J. F. Hodgson gratefully acknowledges a fellowship from the Stanley Thomas Johnson Memorial Fund. The work was supported by a grant from the Medical Research Council.

\section{References}

Bowen, G. E., and Kirsner, J. B. (1965). Positive epinephrine skin test for 'circulating endotoxin' in inflammatory disease of the intestine. American Journal of Clinical Pathology, 44, 642-647.

de Dombal, F. T., Burton, I. L., Clamp, S. E., and Goligher, J. C. (1974). Short-term course and prognosis of Crohn's disease. Gut, 15, 435-443.

Doe, W. F., Booth, C. C., and Brown, D. L. (1973). Evidence for complement binding immune complexes in adult coeliac disease, Crohn's disease and ulcerative colitis. Lancet, 1, 402-403.

Feinstein, P. A., Kaplan, S. R., and Thayer, W. R. (1976). Alternative complement pathway activation in inflamma- 
tory bowel disease: quantitation of $\mathrm{C} 3$ proactivator (factor B) protein. Gastroenterology, 70, 181-185.

Ganrot, K. (1974). Plasma protein pattern in acute infectious diseases. Scandinavian Journal of Clinical and Laboratory Investigation, 34, 75-81.

Gewurz, H., Shin, H. S., and Mergenhagen, S. E. (1968). Interactions of the complement system with endotoxic lipopolysaccharide: consumption of each of the six terminal complement components. Journal of Experimental Medicine, 128, 1049-1057.

Gewurz, H., Pickering, R. J., Naff, G., Snyderman, R., Mergenhagen, S. E., and Good, R. A. (1969). Decreased properdin activity in acute glomerulonephritis. International Archives of Allergy and Applied Immunology, 36, 592-598.

Hodgson, H. J. F., Potter, B. J., and Jewell, D. P. (1975). Complement in inflammatory bowel disease. (Abstract.) Gut, 16, 833-834.

Hodgson, H. J. F., Potter, B. J., and Jewell, D. P. (1977). Immune complexes in inflammatory bowel disease. Clinical and Experimental Immunology. (In press.)

Höyeraal, H. M., and Mellbye, O. J. (1974). High levels of serum complement factors in juvenile rheumatoid arthritis. Annals of the Rheumatic Diseases, 33, 243-247.
Jewell, D. P., and MacLennan, I. C. M. (1973). Circulating immune complexes in inflammatory bowel disease. Clinical and Experimental Immunology, 14, 219-226.

Kohler, P. F., and ten Bensel, R. (1969). Serial complement component alterations in acute glomerulonephritis and systemic lupus erythematosus. Clinical and Experimental Immunology, 4, 191-202.

Pepys, M. B., Druguet, M., Klass, H. J., Dash, A. C., Mirjah, D. D., and Petria, A. (1977). In Immunology of the Gut. Edited by I. Knight. Ciba Foundation Symposium, Elsevier/Excerpta Medica/North-Holland: Amsterdam. (In press.)

Potter, B. J. (1975). Complement Activity in Liver Disease. Thesis: London University.

Potter, B. J., Trueman, A. M., and Jones, E. A. (1973). Serum complement in chronic liver disease. Gut, 14, 451456.

Teisberg, P., and Gjone, E. (1975). Humoral immune system activity in inflammatory bowel disease. Scandinavian Journal of Gastroenterology, 10, 545-549.

Truelove, S. C., and Witts, L. J. (1955). Cortisone in ulcerative colitis: final report on a therapeutic trial. British Medical Journal, 2, 1041-1048.

Ward, M., and Eastwood, M. A. (1974). Serum complement components $\mathrm{C} 3$ and $\mathrm{C} 4$ in inflammatory bowel disease. (Abstract.) Gut, 15, 835. 